\title{
Gonadal function after allogenic bone marrow transplantation for thalassaemia
}

\author{
V De Sanctis, M Galimberti, G Lucarelli, P Polchi, L Ruggiero, C Vullo
}

\begin{abstract}
Thirty prepubertal patients with thalassaemia major (15 boys and 15 girls) aged from 9.3 to 17.2 years (mean 12.9) who had successfully undergone allogenic bone marrow transplantation were studied. Before the transplant all patients were given short courses of high doses of busulphan (total dose $14 \mathrm{mg} / \mathrm{kg}$ ) followed by cyclophosphamide (total dose 200 $\mathrm{mg} / \mathrm{kg}$ ). Pituitary gonadal function was asssessed between 0.7 and 5.1 years (mean 2.3 ) after bone marrow transplantation. Increased gonadotrophin concentrations indicating gonadal damage were found in $80 \%$ of the girls, probably as a result of the chemotherapy. In all the prepubertal boys the basal follicle stimulating hormone and luteinising hormone concentrations were normal. Most of the boys had reduced gonadotrophin and testosterone responses after gonadotrophin releasing hormone and human chorionic gonadotrophin tests. This could have been the result of iron overload but the effect of cytotoxic agents cannot be excluded. These findings emphasise the need for vigilant long term follow up of thalassaemic patients treated with cytotoxic chemotherapy for bone marrow transplantation so that those requiring hormone replacement can be identified and treated.
\end{abstract}

Bone marrow transplantation is a realistic therapeutic option for patients with thalassaemia major. ${ }^{1}$ Intensive short courses of chemotherapy are given before transplantation to eradicate the recipient's own marrow and to produce sufficient immunosuppression to permit allogenic grafting. The adverse effects of chemotherapeutic agents on the gonads have been well documented in adolescents and adults, but less is known about the effects in children. ${ }^{2-4}$

Sanders et al have now provided much needed data on subjects with aplastic anaemia or leukaemia after bone transplantation, ${ }^{4-6}$ but there have been no reports about endocrine function in thalassaemic patients after successful bone marrow transplantation. This is particularly important, as most of these patients have some degree of endocrine dysfunction before transplantation.

In this report we provide data about pituitary gonadal function in a group of prepubertal thalassaemic patients who are long term survivors of bone marrow transplantation.

Patients and methods

We studied 30 prepubertal patients with thalas- saemia major ( 15 boys and 15 girls) aged from $9 \cdot 3$ to $17 \cdot 2$ years (mean 12.9 ) who had successfully undergone allogeneic bone marrow transplantation in the department of haematology at the Ospedale Muraglia, Pesaro, Italy. Sibling donors matched at the major histocompatibility loci were used for transplantation.

Before transplantation the parents were informed of the risks and potential benefits compared with those of conventional treatment with blood transfusions and chelation with desferrioxamine mesylate.

The patients were prepared for the transplant with busulphan $(3.5 \mathrm{mg} / \mathrm{kg}$ body weight) given orally three times a day on four consecutive days, followed by cyclophosphamide $(50 \mathrm{mg} / \mathrm{kg}$ body weight) given intravenously on each of the next four consecutive days, a regimen modified from that first described by Santos. ${ }^{7}$

Marrow was infused 36 hours after the course of cyclophosphamide. Prophylaxis against graft versus host disease (GVHD) consisted of methotrexate in one patient and cyclosporin in 29 patients.

Three patients developed chronic GVHD after transplantation and were treated with long courses of corticosteroids, cyclosporin, and azathioprine. Pituitary gonadal function was assessed from 0.7 to 5.1 years (mean $2 \cdot 3$ ) after bone marrow transplantation, by assaying the concentrations of follicle stimulating hormone and luteinising hormone in blood before and 20, 40,60 , and 120 minutes after intravenous injection $\left(50 \mu \mathrm{g} / \mathrm{m}^{2}\right)$ of gonadotrophin releasing hormone (Relisorm, Biodata). Plasma concentrations of luteinising hormone and follicle stimulating hormone were measured in duplicate with commercial immunoradiometric (IRMA) kits (Serono Laboratories) as follows: luteinising hormone-first international reference preparation $68 / 40$, with intra-assay coefficients of variation of $9 \%$ at $0.5 \mathrm{IU} / 1$, and 3.2 at $50 \mathrm{IU} / 1$; and follicle stimulating hormone-second international reference preparation $78 / 549$, with intra-assay coefficients of variation of $11 \%$ at 0.5 $\mathrm{IU} / 1$ and $2 \cdot 9 \%$ at $50 \mathrm{IU} / 1$.

The basal and peak hormonal responses were compared in the thalassaemic patients and 14 prepubertal controls (seven boys and seven girls) mean (SD) age 10 (1) years (tables 1 and 2).

Leydig cell function in the boys was assessed by measuring the plasma testosterone concentration by radioimmunoassay (RIA) before and 72 hours after stimulation with human chorionic gonadotrophin 2000 units intramuscularly.

Other variables measured were serum basal $17 \beta$-oestradiol in the girls, serum thyroid 
Table 1 Gonadotrophin releasing hormone test: plasma gonadotrophin concentrations and serum basal oestradiol in 15 female thalassaemic patients who had undergone bone marrow transplantation

\begin{tabular}{|c|c|c|c|c|c|}
\hline \multirow[t]{2}{*}{$\begin{array}{l}\text { Case } \\
\text { No }\end{array}$} & \multicolumn{2}{|c|}{$\begin{array}{l}\text { Luteinising hormone } \\
\text { (IU/l) }\end{array}$} & \multicolumn{2}{|c|}{$\begin{array}{l}\text { Follicle stimulating hormone } \\
\text { (IU/l) }\end{array}$} & \multirow[t]{2}{*}{$\begin{array}{l}\text { Oestradiol } \\
\text { (pmolll) }\end{array}$} \\
\hline & Basal & Peak & Basal & Peak & \\
\hline $\begin{array}{r}1 \\
2 \\
3 \\
4 \\
5 \\
6 \\
7 \\
8 \\
9 \\
10 \\
11 \\
12 \\
13 \\
14 \\
15\end{array}$ & $\begin{array}{r}1.8 \\
<0.5 \\
<0.5 \\
0.5 \\
45.0 \\
34.3 \\
2.2 \\
3.3 \\
4.5 \\
13.0 \\
12.6 \\
3.5 \\
9.7 \\
4.9 \\
2.4\end{array}$ & $\begin{array}{r}12.6 \\
<0.5 \\
<0.5 \\
2.0 \\
200.0 \\
134.0 \\
6.1 \\
11.1 \\
16.0 \\
39.0 \\
50.2 \\
13.3 \\
38.4 \\
14.8 \\
7.9\end{array}$ & $\begin{array}{r}12.0 \\
<0.5 \\
<0.5 \\
1.7 \\
114.0 \\
103.0 \\
10.0 \\
12.8 \\
15.5 \\
48.0 \\
62.2 \\
17.6 \\
43.8 \\
16.1 \\
9.6\end{array}$ & $\begin{array}{r}22.0 \\
1.0 \\
1.7 \\
2.7 \\
140.0 \\
140.0 \\
13.3 \\
16.7 \\
24.3 \\
63.0 \\
88.0 \\
23.8 \\
57.3 \\
20.8 \\
12.4\end{array}$ & $\begin{array}{l}<36.7 \\
<36.7 \\
<36.7 \\
<36.7 \\
<36.7 \\
<36.7 \\
<36.7 \\
<36.7 \\
<36.7 \\
<36.7 \\
<36.7 \\
<36.7 \\
<36.7 \\
<36.7 \\
<36.7\end{array}$ \\
\hline
\end{tabular}

Mean (SD) reference ranges:

Luteinising hormone-basal $0.5 \mathrm{IU} / 1$; peak $2.8(1.6) \mathrm{IU} / \mathrm{l}$; range $1.3-6$.

Follicle stimulating hormone-basal $1.9(1.4)$ IU/l, range $0.5-4 \cdot 3$; peak $10(2 \cdot 7)$ IU/h, range 7.9-14.

Oestradiol-basal $<36.7 \mathrm{pmol} / \mathrm{l}$.

Table 2 Gonadotrophin releasing hormone test (plasma gonadotrophins) and human chorionic gonadotrophin test (serum testosterome) in 15 male thalassaemic patients who had undergone bone marrow transplantation

\begin{tabular}{|c|c|c|c|c|c|c|}
\hline \multirow[t]{2}{*}{$\begin{array}{l}\text { Case } \\
\text { No }\end{array}$} & \multicolumn{2}{|c|}{$\begin{array}{l}\text { Luteinising hormone } \\
\text { (IU/l) }\end{array}$} & \multicolumn{2}{|c|}{$\begin{array}{l}\text { Follicle stimulating hormone } \\
\text { (IU/l) }\end{array}$} & \multicolumn{2}{|c|}{$\begin{array}{l}\text { Testosterone } \\
(\text { nmolll })\end{array}$} \\
\hline & Basal & Peak & Basal & Peak & Basal & Peak \\
\hline $\begin{array}{l}16 \\
17 \\
18 \\
19 \\
20 \\
21 \\
22 \\
23 \\
24 \\
25 \\
26 \\
27 \\
28 \\
29 \\
30\end{array}$ & $\begin{array}{l}0.5 \\
0.5 \\
0.6 \\
0.5 \\
0.5 \\
0.5 \\
0.9 \\
0.5 \\
0.8 \\
0.5 \\
0.5 \\
0.5 \\
0.5 \\
0.5 \\
0.6\end{array}$ & $\begin{array}{l}4.2 \\
6.9 \\
0.8 \\
0.7 \\
0.5 \\
0.9 \\
3.4 \\
2.3 \\
4.2 \\
1.7 \\
1.8 \\
0.6 \\
1.1 \\
0.5 \\
1.3\end{array}$ & $\begin{array}{l}1.6 \\
2.9 \\
1.1 \\
0.5 \\
1.0 \\
0.5 \\
1.2 \\
0.5 \\
0.7 \\
1.1 \\
1.6 \\
0.5 \\
0.5 \\
0.5 \\
0.5\end{array}$ & $\begin{array}{r}11.2 \\
6.6 \\
2.3 \\
1.0 \\
1.0 \\
1.9 \\
1.8 \\
0.6 \\
2.8 \\
1.0 \\
2.5 \\
0.6 \\
1.2 \\
0.5 \\
0.7\end{array}$ & $\begin{array}{r}69 \\
49 \\
69 \\
49 \\
69 \\
38 \\
125 \\
69 \\
107 \\
32 \\
104 \\
32 \\
69 \\
80 \\
69\end{array}$ & $\begin{array}{r}208 \\
482 \\
69 \\
270 \\
69 \\
374 \\
277 \\
250 \\
728 \\
180 \\
222 \\
184 \\
139 \\
166 \\
267\end{array}$ \\
\hline
\end{tabular}

Mean (SD) reference ranges:

Luteinising hormone-basal $0.58(0.14) \mathrm{IU} / 1$; range 0.5-0.9; peak $3.6(2.4) \mathrm{IU} / \mathrm{l}$; range 1.4-8.5. Follicle stimulating hormone-basal $1.6(1 \cdot 1)$ IU $/$, range $0.5-3 \cdot 1$; peak $2.7(1 \cdot 1)$ IU/1, range $1 \cdot 8-5 \cdot 8$.

Testosterone-basal 83 (38) nmol/, range 32-139; peak 610 (198) nmol/l, range 368-1002.

Table 3 Details of female thalassaemic patients who have undergone bone marrow transplantation

\begin{tabular}{|c|c|c|c|c|c|c|}
\hline $\begin{array}{l}\text { Case } \\
\text { No }\end{array}$ & $\begin{array}{l}\text { Interval between } \\
\text { transplantation } \\
\text { and study } \\
\text { (years) }\end{array}$ & $\begin{array}{l}\text { Age at } \\
\text { study } \\
\text { (years) }\end{array}$ & $\begin{array}{l}\text { Height } \\
(\mathrm{cm})\end{array}$ & $\begin{array}{l}\text { Weight } \\
(\mathrm{kg})\end{array}$ & $\begin{array}{l}\text { Bone } \\
\text { age } \\
\text { (years) }\end{array}$ & $\begin{array}{l}\text { Serum } \\
\text { ferritin } \\
(\mu g / l)\end{array}$ \\
\hline $\begin{array}{r}1 \\
2 \\
3 \\
4 \\
5 \\
6 \\
7 \\
8 \\
9 \\
10 \\
11 \\
12 \\
13 \\
14 \\
15\end{array}$ & $\begin{array}{l}1.2 \\
3.7 \\
1.0 \\
3.0 \\
1.3 \\
2.5 \\
3.3 \\
4.6 \\
1.8 \\
2.8 \\
2.2 \\
3.3 \\
2.3 \\
0.6 \\
2.0\end{array}$ & $\begin{array}{r}9.3 \\
9.4 \\
11.8 \\
12.0 \\
12.5 \\
12.8 \\
13.0 \\
13.3 \\
13.3 \\
13.5 \\
13.9 \\
14.0 \\
15.0 \\
15.5 \\
16.8\end{array}$ & $\begin{array}{l}130 \cdot 0 \\
135 \cdot 1 \\
127 \cdot 0 \\
135 \cdot 9 \\
140 \cdot 0 \\
144 \cdot 8 \\
139 \cdot 3 \\
147 \cdot 5 \\
152 \cdot 3 \\
142 \cdot 0 \\
160 \cdot 2 \\
147 \cdot 9 \\
145 \cdot 9 \\
152 \cdot 0 \\
152 \cdot 0\end{array}$ & $\begin{array}{l}25 \cdot 3 \\
32 \cdot 0 \\
23 \cdot 3 \\
29 \cdot 7 \\
38 \cdot 0 \\
29 \cdot 0 \\
35 \cdot 5 \\
36 \cdot 0 \\
51 \cdot 7 \\
55 \cdot 0 \\
61 \cdot 8 \\
35 \cdot 9 \\
32 \cdot 9 \\
58 \cdot 2 \\
46.5\end{array}$ & $\begin{array}{r}8 \cdot 0 \\
10 \cdot 7 \\
10 \cdot 0 \\
12 \cdot 3 \\
10 \cdot 0 \\
12 \cdot 0 \\
10.5 \\
12 \cdot 0 \\
11 \cdot 5 \\
11 \cdot 8 \\
14 \cdot 3 \\
13 \cdot 0 \\
11 \cdot 1 \\
12.3 \\
12.5\end{array}$ & $\begin{array}{r}925 \\
2905 \\
2125 \\
3150 \\
1840 \\
4030 \\
2085 \\
935 \\
1380 \\
2050 \\
1175 \\
2120 \\
5500 \\
2705 \\
1795\end{array}$ \\
\hline
\end{tabular}

stimulating hormone, thyroxine, bone age, and serum ferritin concentrations using radioimmunoassay as previously described. ${ }^{8}$ Sexual maturation was assessed using the criteria laid down by Tanner. ${ }^{9}$ Bone age was estimated in all patients by the same observer (VDS) using the TW2 method. ${ }^{10}$ Results are expressed as mean
(SD). Statistical analysis was by the Wilcoxon rank sum test; probabilities of $<0.05$ were accepted as significant.

\section{Results}

Table 3 and 4 show the main clinical and laboratory features in female and male thalassaemic patients. All had normal thyroid function.

GONADAL PITUITARY FUNCTION IN GIRLS (table 1) Before bone marrow transplantation the plasma gonadotrophin concentrations (assayed by RIA with polyclonal antibody) of all 15 patients were in the middle to lower parts of the reference ranges: luteinising hormone-mean $2.8 \mathrm{IU} / 1$, range $1 \cdot 5-5 \cdot 0$, controls $3 \cdot 1 \mathrm{IU} / 1$, range $1 \cdot 6-4 \cdot 2$; follicle stimulating hormone-mean $2.9 \mathrm{IU} / 1$, range $2-6$, controls $4 \cdot 2 \mathrm{IU} / \mathrm{ml}$, range $3 \cdot 1-6 \cdot 2$.

After bone marrow transplantation $12(80 \%)$ had evidence of primary ovarian dysfunction as judged by raised basal serum gonadotrophin concentrations. The patients' basal values of luteinising hormone ranged from $<0.5$ to 45.0 IU/1 (controls 0.5 ) and basal values of follicle stimulating hormone from $<0.5$ to $114 \mathrm{IU} / 1$ (controls $0 \cdot 5-4 \cdot 3$ ). After injection of gonadotrophin releasing hormone peak luteinising hormone and follicle stimulating hormone concentrations were usually considerably higher than in controls except in cases 2 and 3 who also had low basal values, and in case 4, who had an isolated low follicle stimulating hormone response.

The basal oestradiol values in both the thalassaemic patients and the prepubertal controls were below the sensitivity of the assay (36.7 pmol/l); hence they could not be analysed.

There was no association between increased gonadotrophin concentrations and the age of the patients. Serum ferritin concentrations ranged from 925 to $5500 \mu \mathrm{g} / \mathrm{l}$, mean $2314 \mu \mathrm{g} / \mathrm{l}$ (control: range $14-148 \mu \mathrm{g} / \mathrm{l})$.

GONADAL PITUITARY FUNCTION IN BOYS (table 2) Before bone marrow transplantation basal gonadotrophin concentrations of all 15 patients were in the middle to lower parts of the reference ranges: luteinising hormone-mean $2 \cdot 3 \mathrm{IU} / 1$, range $2-6$; controls $3.5 \mathrm{IU} / \mathrm{l}$, range 1.7-5.7; follicle stimulating hormone-mean $2 \cdot 4 \mathrm{IU} / \mathrm{l}$, range $1-3 \cdot 5$; controls $3.8 \mathrm{IU} / \mathrm{l}$, range 1·7-6.3. After transplantation all had basal luteinising hormone and follicle stimulating hormone concentrations within the control range: luteinising hormone 0.5-0.9 IU/1 (controls $0.5-0.8)$, and follicle stimulating hormone 0.5-2.9 IU/1 (controls 0.5-3.1).

After the gonadotrophin releasing hormone test three patterns of response were observed: Three patients $(22,24$, and 26$)$ had stimulated gonadotrophin concentration within the control range, two (16 and 17) showed a follicle stimulating hormone response greater than the controls, and 10 (18-21, 25, and 27-30) had significantly lower luteinising hormone or follicle stimulating hormone concentrations (or both) 
Table 4 Details of male thalassaemic patients who have undergone bone marrow transplantation

\begin{tabular}{|c|c|c|c|c|c|c|}
\hline $\begin{array}{l}\text { Case } \\
\text { No }\end{array}$ & $\begin{array}{l}\text { Interval between } \\
\text { transplantation } \\
\text { and study } \\
\text { (years) }\end{array}$ & $\begin{array}{l}\text { Age at } \\
\text { study } \\
\text { (years) }\end{array}$ & $\begin{array}{l}\text { Height } \\
(\mathrm{cm})\end{array}$ & $\begin{array}{l}\text { Weight } \\
\text { (kg) }\end{array}$ & $\begin{array}{l}\text { Bone } \\
\text { age } \\
\text { (years) }\end{array}$ & $\begin{array}{l}\text { Serum } \\
\text { ferritin } \\
(\mu g / l)\end{array}$ \\
\hline $\begin{array}{l}16 \\
17 \\
18 \\
19 \\
20 \\
21 \\
22 \\
23 \\
24 \\
25 \\
26 \\
27 \\
28 \\
29 \\
30\end{array}$ & $\begin{array}{l}1.5 \\
5.1 \\
1.9 \\
3.4 \\
1.7 \\
3.3 \\
3.0 \\
1.7 \\
2.5 \\
2.2 \\
2.2 \\
2.0 \\
1.3 \\
2.1 \\
1.4\end{array}$ & $\begin{array}{r}6 \cdot 2 \\
10 \cdot 0 \\
10 \cdot 1 \\
10 \cdot 0 \\
10 \cdot 4 \\
10 \cdot 5 \\
13 \cdot 0 \\
13 \cdot 7 \\
14 \cdot 1 \\
15 \cdot 0 \\
15 \cdot 3 \\
15 \cdot 3 \\
15.5 \\
16.8 \\
17 \cdot 2\end{array}$ & $\begin{array}{l}118.0 \\
137.6 \\
127.5 \\
138.0 \\
134.0 \\
130.5 \\
166.5 \\
149.0 \\
136.7 \\
143.7 \\
149.3 \\
159.0 \\
147.5 \\
150.0 \\
148.5\end{array}$ & $\begin{array}{l}25 \cdot 1 \\
34 \cdot 5 \\
29 \cdot 0 \\
45 \cdot 5 \\
29 \cdot 0 \\
26 \cdot 5 \\
64 \cdot 5 \\
38 \cdot 5 \\
25 \cdot 0 \\
32 \cdot 4 \\
47 \cdot 7 \\
47 \cdot 3 \\
36 \cdot 5 \\
47 \cdot 2 \\
40 \cdot 0\end{array}$ & $\begin{array}{r}7.0 \\
11.0 \\
10.0 \\
10.4 \\
10.0 \\
11.1 \\
14.0 \\
11.8 \\
10.3 \\
12.6 \\
13.1 \\
14.8 \\
11.6 \\
13.2 \\
14.6\end{array}$ & $\begin{array}{r}735 \\
2490 \\
3210 \\
1010 \\
2835 \\
1485 \\
1970 \\
6325 \\
5750 \\
2125 \\
1945 \\
4045 \\
4140 \\
1460 \\
1605\end{array}$ \\
\hline
\end{tabular}

than the prepubertal controls: luteinising hormone $1.04(0.58)$ IU/1 (controls $3.6(2.4)$ ) $(\mathrm{p}<0.01)$, and follicle stimulating hormone 1.08 $(0.59) \mathrm{IU} / 1$ (controls $2 \cdot 7(1 \cdot 1))$, (p<0.01).

The basal serum testosterone concentrations in the patients did not differ significantly from those of prepubertal controls: 69 (27) $\mathrm{nmol} / \mathrm{l}$ compared with controls 83 (38). Intramuscular injection of human chorionic gonadotrophin produced a variable response. Three patients (cases 17, 21, and 24) responded normally (range 413-728 nmol/1), 10 (cases 16, 19, 22, 23, and 25-30) had an inadequate response (range 139-277 nmol/l); two (cases 18 and 20) showed no response. The normal basal and peak testosterone levels are given in the footnote to table 2. Serum ferritin concentrations ranged from 735 to $6325 \mu \mathrm{g} / 1$ (mean 2742) (control range 14-148).

\section{Discussion}

Increased gonadotrophin concentrations indicating gonadal damage were found in most of the thalassaemic girls but those in the prepubertal thalassaemic boys were within the reference range. A normal follicle stimulating hormone concentration before puberty, however, does not preclude germinal epithelial damage. A secondary abnormal increase in gonadotrophin concentrations after the onset of puberty has been reported after treatment in prepubertal boys with acute lymphatic leukaemia or Hodgkin's disease, ${ }^{11}$ and in patients with gonadal dysgenesis ${ }^{11}$ or Klinefelter's syndrome. ${ }^{13}$

In most prepubertal thalassaemic boys the gonadotrophin and testosterone responses were reduced after the injections of gonadotrophin releasing hormone and human chorionic gonadotrophin. This has also been reported in thalassaemic patients who have not undergone bone marrow transplantation, ${ }^{14-17}$ and has been attributed to iron deposition in the pituitary and to chronic hepatitis. ${ }^{15} 16$ Iron overload could be a factor in our patients but a direct effect of cytotoxic agents on the gonads cannot be excluded.

Our observations in prepubertal patients show that whereas there is no obvious gonadal damage in boys as a result of the chemotherapy used before bone marrow transplantation, there is serious damage to the gonads on girls. It is likely that this is the result of the toxic effects of the drugs given in the conditioning phase, but because of the combinations of drugs it is difficult to identify which one was responsible for the gonadal damage.

Our patients received short term chemotherapy with cyclophosphamide (total dose 200 $\mathrm{mg} / \mathrm{kg}$ ) and busulphan (total dose $14 \mathrm{mg} / \mathrm{kg}$ ) before allogeneic bone marrow transplantation. Cyclosporin or methotrexate were used for prophylaxis against GVHD. Others have reported that ovarian damage seems to be correlated with the dose of cyclophosphamide given. Thus in patients with aplastic anaemia and leukaemia $500 \mathrm{mg} / \mathrm{kg}$ given before bone marrow transplantation caused ovarian failure, whereas $200 \mathrm{mg} / \mathrm{kg}$ seemed to have little toxic effect in 18 prepubertal girls whose subsequent pubertal development and menstrual function were normal. ${ }^{18}$ It has been suggested, however, that cyclophosphamide results in ovarian dysfunction when used in combination with other drugs. ${ }^{19}$ In rats busulphan given during pregnancy causes the selective disappearance of fetal oocytes. ${ }^{20} \mathrm{~A}$ similar effect has been reported in humans. ${ }^{21}$ The effects of cyclosporin on the gonads in humans are not yet known, although dysfunctional and structural injury have been shown in the ovaries of rabbits given the drug. ${ }^{22}$

In interpreting our data it is important to remember that even in thalassaemic patients who have not had bone marrow transplantation studies of histological appearance and hormonal function have shown a reduction in the number of primordial follicles ${ }^{23}$ and impaired gonadal function. ${ }^{25}$

There was a wide variation in the increase of gonadotrophins found in the female patients that we studied. Transitory increased secretion has been reported in leukaemic children during induction chemotherapy, ${ }^{26}$ and in two prepubertal girls treated with spinal irradiation. ${ }^{27}$ It is unlikely that an acute effect of chemotherapy influenced the investigation of our patients. The wide range luteinising hormone and follicle stimulating hormone values in our patients might be explained by previous pituitary involvement, which we have found to be common in thalassaemic patients who have regularly been transfused. ${ }^{25}$

Our findings have several implications. Successful bone marrow transplantation is considered a radical cure for thalassaemia. The results of this study, however, seem to indicate that it has the serious drawback of gonadal damage, which will have a deleterious effect on the quality of life. There is no doubt that this must be taken into account when discussing the pros and cons of bone marrow transplantation with the patient and parents. It must also be remembered, however, that when thalassaemia major is treated in the traditional manner, delayed puberty or absence of puberty is the most common endocrine disorder ${ }^{28}$ and many girls-even though they start to menstruatewill have secondary amenorrhoea. ${ }^{8}$ There are few thalassaemic girls who are fertile or in whom fertility can be induced. In addition, prolonged follow up after bone marrow trans- 
plantation is necessary before it is certain that gonadal damage is permanent, because some leukaemic subjects have undergone pubertal development in spite of the fact that their gonads have been damaged by treatment before puberty. ${ }^{29}$

This study is the first that we know of on pituitary gonadal function in prepubertal thalassaemic patients after successful bone marrow transplantation. Our data indicate that more experimental work is needed to design conditioning chemotherapy that will be both effective and non-toxic, and to find out how to prevent damage by cytotoxic agents to the patient's gonads. Glode et al found that in mice giving [D-]leu]-des-Gly- $\mathrm{NH}_{2}$ proethylamide gonadotrophin releasing hormone protected the testes from damage induced by cyclophosphamide. ${ }^{30}$ It is important that functional studies of the hypothalamic pituitary gonadal axis and long term surveillance should be carried out in thalassaemic patients who have undergone bone marrow transplantation. Only in this way can those requiring hormone replacement be identified and treated and this would avoid both the impairment of growth and sexual development that affect their social life.

We are grateful to Dr Barbara Anderson for her valuable comments during the preparation of the manuscript and to Mrs Nadia Baraldi for her secretarial help.

1 Lucarelli G, Galimberti M, Delfini C, et al. Marrow transplantation for thalassaemia following busulphan and cyclophosphamide. Lancet 1985;i:1355-7.

2 Benker G, Schafer U, Hermanns U, et al. Allogenic bone marrow transplantation in adults: endocrine sequic bone 1-6 years. Acta Endocrinol 1989;120:37-42.

3 Sklar CA, Kim TH, Williamson F, Ramsay NKC. Ovarian function after successful bone marrow transplantation in function after successful bone marrow transplantation in

4 Sanders JE, Buckner CD, Amos D, et al. Ovarian function following marrow transplantation for aplastic anemia or following marrow transplantation for

5 Sanders JE, Buckner CD, Leonard JM, et al. Late effects on gonadal function of cyclophosphamide, total-body irradiation, and marrow transplantation. Transplantation 1983;36: 252-5.

6 Sanders JE, Pritchard S, Mahoney P, et al. Growth and development following marrow transplantation for leukemia. Blood 1986;68:1129-34

7 Santos GW. Immunosuppression for clinical marrow transplantation. Semin Hematol 1974;11:341-51.

8 De Sanctis V, Vullo C, Katz M, et al. Hypothalamic- pituitary-gonadal axis in thalassaemic patients with secondary amenorrhoea. Obstet Gymecol 1988;72:643-7.

Tanner JM. Growth at adolescence. 2nd Ed. Oxford: Blackwell, 1966:32.

10 Tanner JM, Whitehouse RH, Marshall WA, Healy MJ, Goldstein $\mathrm{H}$. Assessment of skeletal maturity and prediction of adult height (TW2 method). New York: Academic Press, 1975.

11 Wang C, Ronald P, Chan TK, Todd D. Effect of combinaion chemotherapy on pituitary-gonadal function in patients with lymphoma and leukemia. Cancer 1980;45:2030-7.

12 Conte FA, Grumbach MM, Kaplan SL, Reiter EO. Correlation of luteinizing hormone-releasing factor induced luteinizing hormone and follicle-stimulating hormone release from infancy to 19 years with the changing pattern of gonadotropin secretion in agonadal patients relation to the restraint of puberty. F Clin Endocrinol Metab 1980;50: restrain

13 Salbenblatt JA, Bender BG, Puck MH, et al. Pituitarygonadal function in Klinefelter syndrome before and during puberty. Pediatr Res 1985;19:82-6.

14 Anoussakis CH, Alexiou D, Abatzis D, Bechrakis G. Endocrinological investigation of pituitary gonadal axis in thalassaemia major. Acta Paediatr Scand 1977;66:49-51.

15 Landau H, Spitz IM, Cividalli G, Rachmilewitz E. Gonadotrophin, thyrotrophin and prolactin reserve in $\beta$-thalassaemia. Clin Endocrinol 1978;9:163-73.

16 De Sanctis V, Atti G, Lucci M, et al. Endocrine assessment of hypogonadism in patients affected by thalassaemia major. La Ricerca Clinica e Laboratoria 1980;10:663-71.

17 De Sanctis V, Vullo C, Katz M, et al. Induction of spermatogenesis in thalassaemia. Fertil Steril 1988:50: 969-75.

18 Sanders JE, Buckner CD, Sullivan KM, et al. Growth and development in children after bone marrow transplantation. Horm Res 1988;30:92-7.

19 Chapman R. Gonadal injury resulting from chemotherapy. Am $\mathcal{F}$ Ind Med 1983;4:149-52.

20 Heller RH, Jones JW. Production of ovarian dysgenesis in the rat and humans by busulfan. Am $\mathcal{F}$ Obstet Gynecol the rat and hum

21 Belhorsky B, Siracky J, Sander L, Klouber E. Comments on the development of amenorrhea caused by myleran in cases of chronic myelosis. Neoplasma 1960;7:397-403.

22 Al Chalabi HA. Effect of cyclosporin A on the morphology and function of the ovary and fertility in the rabbit. Int $\mathcal{f}$ Fertil 1984;29:218-23.

23 Costin G, Kogut MD, Hyman CB, Ortega JA. Endocrine abnormalities in thalassaemia major. Am $\dot{f}$ Dis Child 1979;133:497-502.

24 Zaino EC, Kuo B, Roginsky MS. Growth retardation in thalassaemia major. Ann NY Acad Sci 1964;165:394-9.

25 De Sanctis V, Vullo C, Katz M, et al. Gonadal function in patients with $\beta$-thalassaemia major. $\mathcal{F}$ Clin Pathol 1988;41: 133-7.

26 Beck W, Schartz S, Heidemann PH, et al. Hypergonadotropic hypogonadism, SHBG deficiency and hyperprolactinaemia: a transient phenomenon during induction chemotherapy in leukemic children. Eur $¥$ Pediatr 1982;138:216-20.

27 Livesey EA, Brook CGD. Gonadal dysfunction after treatment of intracranial tumours. Arch Dis Child 1988;63: ment of

28 Borgna Pignatti C, De Stefano P, Zonta L, et al. Growth and sexual maturation in thalassaemia major. $\mathcal{F}$ Pediatr 1986; 106:150-5.

29 Quigley C, Cowell C, Jimenez M, et al. Normal or early development of puberty despite gonadal damage in children treated for acute lymphoblastic leukemia. N Engl $\mathcal{F}$ Med 1989;321:143-51.

30 Glode LH, Robinson J, Gould SF. Protection from cyclophosphamide-induced testicular damage with an analogue of gonadotropin-releasing hormone. Lancet 1981;i:1132-4. 